\title{
THE ROLE AND IMPORTANCE OF IRRIGATION SYSTEM FOR INCREASING THE WATER RESOURCES: THE CASE OF THE NIDA RIVER VALLEY
}

\author{
Łukasz Borek $^{1 \bowtie}$, Karolina Drymajto² \\ ${ }^{1}$ Department of Land Reclamation and Environmental Development, Faculty of Environmental Engineering and Land Surveying, \\ University of Agriculture in Krakow, Al. Mickiewicza 24/28, 30-059 Krakow \\ 2 Teldraft Sp. z.o.o. - engineering activities and technical consulting
}

\begin{abstract}
\section{Aim of the study}

This paper presents the role and importance of the gravity-fed irrigation system for increasing the soil water resources and surface retention in sandy alluvial soils.
\end{abstract}

\begin{abstract}
Material and methods
The research was conducted on the Kopernia object (64.2 ha) within the Nida River Valley (Pińczów County, Świętokrzyskie Voivodeship) focused on the sub-irrigation systems formed in the second half of the 20th century. In order to identify the changes in soil water retention at the object, certain characteristics of soil profile were measured, such as gravitational water and volumetric water content in alluvial soil at different depths of groundwater table position. For determining surface retention the archival materials (technical project) as well as field tests e.g. ditch inventorisation, soil samples collection, were used. Additionally, in laboratory, the selected physical and water properties of alluvial soils were determined.
\end{abstract}

\begin{abstract}
Results and conclusions
On the basis of both the inventorisation of ditches and hydrotechnical constructions as well as field and laboratory tests, it was shown that during the proper operation of the irrigation system, water can be stored in the soil profile in the amount from $42115.2 \mathrm{~m}^{3}$ to $62916 \mathrm{~m}^{3}$, with $10821 \mathrm{~m}^{3}$ of water in the ditches as a result of surface retention. Some of irrigation systems could be used to expand wetlands, also to increase small water retention. However, such changes would require large financial contributions and time to carry out these adjustments to current water policy and climate change.
\end{abstract}

Keywords: climate change, surface retention, soil water resources, open ditches, irrigation system

\section{INTRODUCTION}

The increasing frequency of droughts draws more attention to rational management of water in agroecosystems. One of the methods of water retention in the agricultural space is its accumulation in open ditches and canals. The gravity-fed irrigation systems and hydrotechnical structures are one of the most common elements of technical infrastructure that can be found in rural areas in Poland, Europe and other parts of the world. They play a significant role in improving agricultural production, biodiversity, shaping the land-

凶e-mail: lukasz.borek@urk.edu.pl 
scape and the hydrological cycle of small rural catchment (Leibundgut and Kohn, 2014a, b; Borek and Ostrowski, 2014; Carlson et al., 2019).

According to the Polish Water Law from 20th June 2017 water facilities are defined as: ,, devices or structures for the development of water resources and the use of these resources, including: a) devices or damming structures, flood protection and regulation structures, and also canals and ditches" (DZ.U. z 2017 poz. 1566).

Irrigation systems are not the latest trend in agriculture. Archaeological research, carried out in all around the world, shows that the development of hydrotechnical ideas is dated several thousand years B.C. Irrigation systems were used in ancient times, inter alia, in Mesopotamia, Egypt, India, China, Peru and Sri Lanka, having a positive impact on the development of settlements and agriculture (Meijer, 2006; Ertsen, 2010; Mays, 2010; Zaghloul et al., 2013).

Currently, the biggest problem of water management, apart from climate change, is the negligence of drainage and irrigation infrastructure due to lack of proper operation and maintenance. Decapitalised ditches, canals and weirs cause changes in the ecosystems and the loss of water, resources of which shrink year after year (Łabędzki, 2007). Considering rational water management in the light of apparent climate change, attention should be paid to the modernization and automation of existing and newly designed irrigation and drainage systems (Lecina et al., 2010; Lozano et al., 2010; Alarcón et al., 2015; Wahlin and Zimbelman, 2017; Vassena et al., 2012).

Gravity irrigation systems were mainly used for supplying water to permanent grassland, which occupy over 3 billion hectares of land on our planet, accounting for slightly more than $23 \%$ of land areas (Burczyk et al., 2018). In Poland, meadows and pastures constitute about $10 \%$ of the country's area and over $20 \%$ of agricultural land (GUS, 2017). These are mainly areas of rivers, forests or wetlands. Drainage or irrigation of arable lands allows increasing crops even twice (Pierzgalski, 1990). A distinctive feature of the Nida River Valley is the dense network of drainage and irrigation ditches and channels supplying water to permanent grasslands. The use of meadows in the Nida Valley in the 20th century was very intense - cattle and horses were most commonly kept (in Michałów there is one of the largest stud of Arabian horses in Poland). In the course of time interest of irrigation dropped for several years. In the Nida River Valley a lot of the remains of old irrigation systems were found, covering large area. Still, these systems have an impact on the wetness of soil and biodiversity of meadows. This area's unique qualities are evidenced by the fact that part of the Nida Valley it has been included in the Natura 2000 nature conservation programme.

Under the EU LIFE+ programme, which started in spring 2019, in the middle parts of Nida River's basin efforts were being made to create a stable restoration of the environmental and biodiversity. In particular, this involves rebuilding irrigation infrastructures for reintroducing freshwater turtles, aquatic birds and newts.

The aim of the work was to assess the possibility of increasing water retention in soil on the basis of constant water characteristics of the soil profile, and also of surface retention based on the design and present parameters of ditches on the Kopernia object. The hypothesis was that poor technical condition of the irrigation infrastructure due to the lack of maintenance and exploitation has an impact on reduction of soil and surface retention.

\section{MATERIALS AND METHODS}

\section{Description of study area}

The irrigation system Nida-Pińczów extends through alluvial soils located in the Nida River Valley that consists of permanent grasslands in Pińczów County, Świętokrzyskie Voivodeship (Poland). The average altitude of the object is between 180.00 and $190.00 \mathrm{~m}$ a.s.l. The whole compound includes four objects - Pińczów, Michałów, Kopernia and Skrzypiów, with the total area of 407 hectares. The Nida River is a left-bank tributary of the Vistula River with the length of $151.2 \mathrm{~km}$ and a total catchment area of $3865.4 \mathrm{~km}^{2}$, hydrographically is a 2nd class watercourse. The Nida River is situated in the European Watershed and is part of the catchment area of the Baltic Sea. This river is formed by joining together of the White Nida and the Black Nida near Chęciny town. It is a typical lowland river with a very low slope. It has a wide floodplain terrace covered with meadows. In the Nida River basin we can find many ditches and irrigation canals. It is one of the warmest Polish rivers. The summer water temperature reaches $27^{\circ} \mathrm{C}$ (Lajczak, 2006, Łapuszek, 2011). 


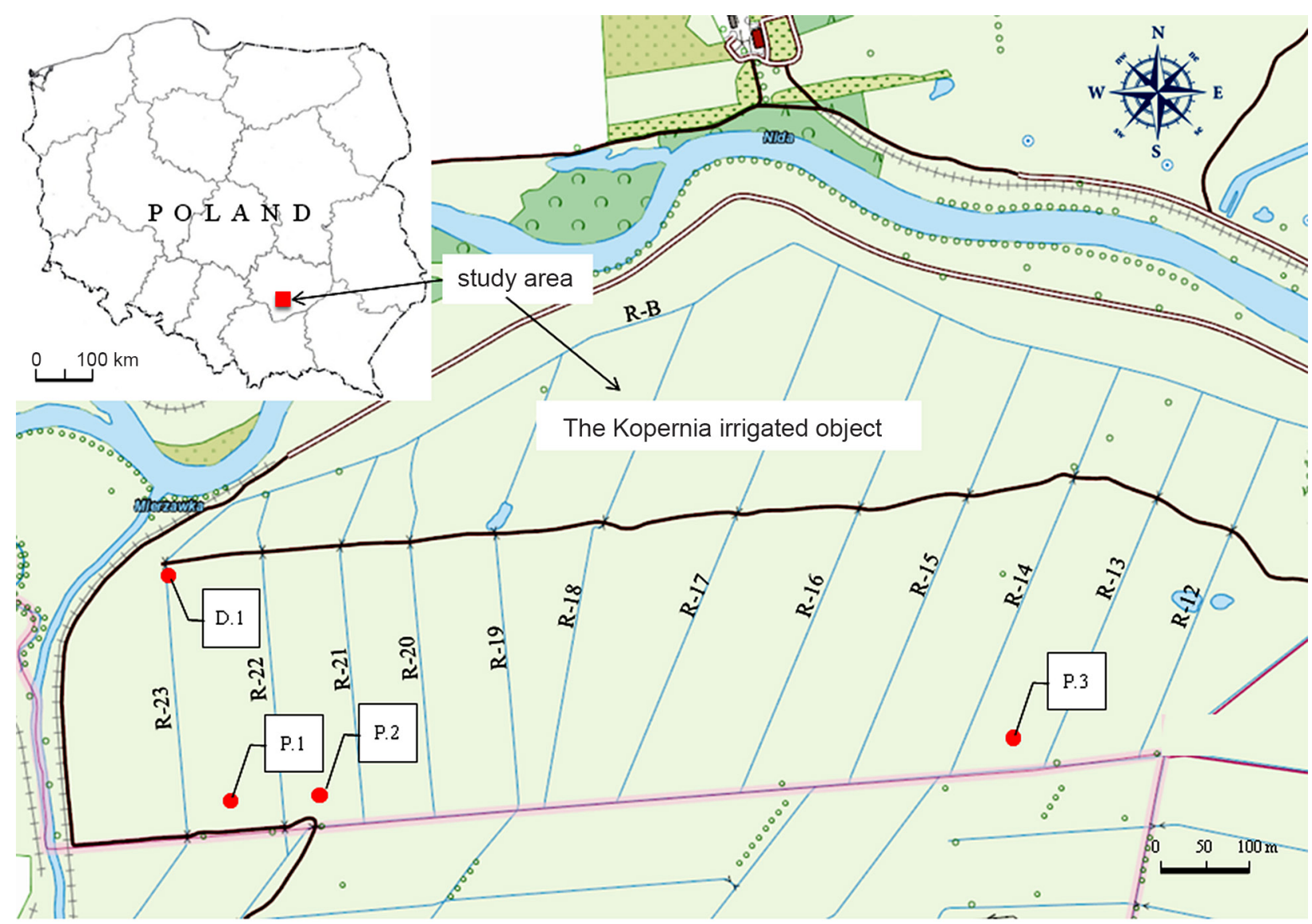

Fig. 1. Location of irrigation system with measurement points; Explanations: P.1-P.3 - location of measurements points in the field; D.1 - location of measurement point in the bottom of the ditch; R-12 - name and nummber of the ditch

According to the geographical division by Kondracki (2011), the irrigation system is situated in the Polish Upland province (34), in the macroregion of the Niecka Nidziańska (342.2) and in the mesoregion of the Nida Valley (342.25).

\section{The scope of research}

- Analysis of the project documentation, such as situation and elevation plan at a scale of $1: 10000$ and profiles of ditches. The Kopernia object with an area 64.2 hectares was selected for detailed analysis and research.

- Inventorisation of 12 irrigation ditches carried out on 19th September 2017 and 23rd April 2018. Ditch inspections were conducted with a tape measure and a level staff. At the beginning and end of each ditch, the following parameters were determined: bottom width (b) and height of the canal (h).

- Soil samples collected on 20th April 2018 - On the Kopernia object three measurements points were installed (P.1, P.2 and P.3), which were located between ditches (in the middle of field) and one point was installed directly in the bottom of the ditch No. R-23 (D.I). Undistarbed soil samples were taken from a depth of $15 \mathrm{~cm}$ and $35 \mathrm{~cm}$ using Kopecky's cylinders (in 3 replications) - only samples from bottom of the ditch No. R-23 from layer of $60 \mathrm{~cm}$ were taken. Also, approximately $1 \mathrm{~kg}$ of disturbed soil was extracted to examine soil texture, and other laboratory analysis was undertaken. In one case, using hole digger, probing was conducted to a depth of $150 \mathrm{~cm}$, during which ground water at a depth of about $1.00 \mathrm{~m}$ below the surface was found. 
- Laboratory analysis - from soil samples that were collected, the selected physical properties were determined in accordance with the general methodologies stated in Mocek and Drzymała (2010): soil texture by the Bouyoucose-Casagrande areometric method modified by Prószyński was specified (PN-R-04032:1998). The content of particle size classes (sand, $2.0-0.05 \mathrm{~mm}$; silt, $0.05-0.002 \mathrm{~mm}$; clay, $<0.002 \mathrm{~mm}$ ) was determined according to the USDA classification (Soil Survey Staff 1999); particle density by the pycnometer method assumed as mean density of the mineral grains of the soil; soil bulk density by the gravimetric method in Kopecky's cylinders $\left(100 \mathrm{~cm}^{3}\right)$ - as the mass of dry soil per volume. The weight of this soil core is then determined after drying in an oven at $105^{\circ} \mathrm{C}$ for about $18-24$ hours; soil moisture by the gravimetric method in Kopecky's cylinders $\left(100 \mathrm{~cm}^{3}\right)$ - as the ratio of the amount of water in the soil sample to the dry weight of the soil, after drying in an oven at $105^{\circ} \mathrm{C}$ for about 18-24 hours; water storage in layer - as soil moisture and thickness of the soil layer $(\mathrm{cm})$, assuming that the first layer is thickness at $10 \mathrm{~cm}$ of depth and second layer at $25 \mathrm{~cm}$. On the basis of results, total porosity was calculated from bulk density and particle density.

- Determination of the soil water retention - soil water retention was calculated based on groundwater table fluctuations $\left(\mathrm{h}_{1}=1.00 \mathrm{~m}-\right.$ intial water level, $\mathrm{h}_{2}=0,70 \mathrm{~m}-$ maximum draining standard, $h_{3}=0,50 \mathrm{~m}-$ minimum draining standard and $h_{4}=0,00 \mathrm{~m}-$ ground level), and also granulometric composition, in particular, the percentage of fraction below $0.02 \mathrm{~mm}$. For this purpose, the following water characteristics of the soil profile were used (Somorowski, 1971):

- net irrigation dose - it is the difference between field capacity at minimum groundwater table and the water resources at maximum groundwater table (at permanent wilting point):

$$
d_{n}=V W_{h \max }-G W_{h \min }[\mathrm{mm}]
$$

where:

$V W_{h \max }-$ volumetric water content at maximum groundwater table, $\begin{aligned} & G W_{h \min }- \text { gravitational water at minimum ground- } \\ & \text { water table. }\end{aligned}$

- Gravitational water (GW) refers to the amount of water held by the soil between saturation and field capacity. It is free water moving through soil by the force of gravity:

$$
G W=a \cdot h_{\min }^{1,73}[\mathrm{~mm}]
$$

- The volumetric water content (VW) is the total amount of water held in a given soil volume at a given time. It includes all water that may be present including gravitational and available water content:

$$
V W=b \cdot h_{\max }^{1,43}[\mathrm{~mm}]
$$

where:

$h_{\min }-$ minimum groundwater level [m],

$h_{\max } \quad-$ maximum groundwater level [m],

$a$ and $b-$ empirical coefficients depending on the percentage content of fraction below $0.02 \mathrm{~mm}$ in the soil. The values specified are taken from the table 1 .

Table 1. Values of empirical coefficients

\begin{tabular}{ccccccccc}
\hline & \multicolumn{8}{c}{ The percentage of fraction below $0.02 \mathrm{~mm}$} \\
\cline { 2 - 9 } Coefficients & 1 & 5 & 10 & 15 & 20 & 35 & 50 & 60 \\
\hline a & 273 & 128 & 92 & 76 & 66 & 51 & 43 & 40 \\
\hline b & 290 & 168 & 133 & 116 & 105 & 87 & 77 & 73 \\
\hline
\end{tabular}

Calculation of the change in soil retention for different variants of groundwater level:

- increase in soil retention as a result of increasing the groundwater table by $\Delta \mathrm{h}_{1-2}$ from the level $\mathrm{h}_{1}$ to $\mathrm{h}_{2}$ :

$$
d n_{1}=V h_{1}-Q h_{2}[\mathrm{~mm}]
$$

- increase in soil retention as a result of increasing the groundwater table by $\Delta \mathrm{h}_{1-3}$ from level $\mathrm{h}_{1}$ to $\mathrm{h}_{3}$ :

$$
d n_{2}=V h_{1}-Q h_{3}[\mathrm{~mm}]
$$

- increase in soil retention as a result of increasing the groundwater table by $\Delta h_{1-4}$ from level $h_{1}$ to $h_{4}$ : 


$$
d n_{3}=V h_{1}-Q h_{4}[\mathrm{~mm}]
$$

- determination of the surface retention of the object - the calculation of the water volume (V) available for storage in ditches (in $\mathrm{m}^{3}$ ) was made based on the scheme (see: Fig. 2) and formula:

$$
V=A \cdot L\left[\mathrm{~m}^{3}\right]
$$

where:

$A$ - surface of cross-section calculated from formula $A=b \cdot h+m \cdot h^{2}\left[\mathrm{~m}^{2}\right]$,

$L$ - length of the ditch $[\mathrm{m}]$

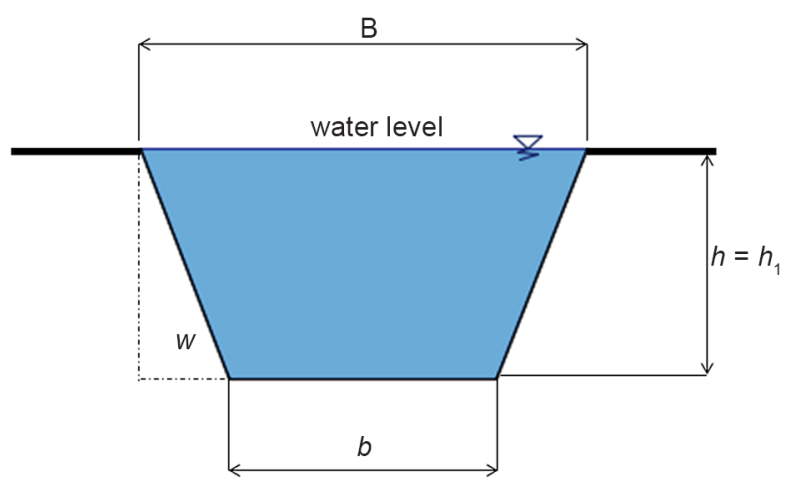

Explanations:

B - top width of the canal/ditch [m],

$b$ - bottom width [m],

$h$ - height of the canal/ditch [m],

$h_{1}$ - depth of the water in the canal/ditch [m],

$w$ - side slope of the canal/ditch $1: \mathrm{m}$

It was assumed that the weirs damming was measured from ground level.

Fig. 2. A trapezoidal ditch cross-section

\section{Statistical analysis}

The data set consisted of analytical results of soil samples collected at the four soil measurement points located in the Nida River Valley during field tests (20th April 2018). Procedures provided by the program Statistica PL version 12.5 with a sample size of $\mathrm{n}=21$ were used for statistical analysis. For each analysed physical and water parameters of soil, basic descriptive statistics such as minimum and maximum values, arithmetic mean, median, standard deviation (SD) and coefficient of variation $(\mathrm{CV})$ were computed.

\section{RESULTS}

\section{Design assumptions and the current status of the irrigation system}

As shown in table 2, ditches are in poor condition, it is clear especially in trapezoidal parameters of the cross-sections, such as bottom width (b) and height (h). As is apparent from the draft, the total length of 12 ditches is 7589 meters. In most cases ditches had a smaller height than in the technical project, because of $0.17 \mathrm{~m}$ mud on mean was observed at the bottom of ditches. The ditch bottoms and the banks are covered with reeds, grass, bushes, and short trees (see: Fig. 3). The bottom width of each ditch, according to the project was $0.5 \mathrm{~m}$, but now ranges from 0.35 to $1.05 \mathrm{~m}$. Changes in trapezoidal cross-section affect the surfaces and volumes of ditches.

Weirs in ditches that had the simplest form consisted of a wall of concrete with a rectangular opening with fixed dimensions $(0.60 \mathrm{~m})$ cut in its edge (see: Fig. 4).

\section{Soil characteristics}

As shown in table 3, the alluvial soils in the Nida River Valley are heterogeneous in terms of texture. Sand was the dominant texture in soil (mean of 68.6\%). Soil color was $10 \mathrm{Y} 2 / 1$ in the topsoil, while at depth of $35 \mathrm{~cm}$ the color changed to $5 \mathrm{Y} 5 / 1$ in point No P.3 and 10Y 5/1 in points No P.1 and P.2. The granulometric composition of the measurement points was classified into to four soil texture groups (acc. to USDA) as: sandy loam, sand, clay loam and loamy sand. The highest CV was in clay (71.8\%). Sand content in the measurement points was between 42 and $96 \%$, silt content between 2 and $29 \%$, and clay content between 2 and $65 \%$. According to the Polsish Soil Classification (PTG, 2011), World Reference Base for Soil Resources - IUSS Working Group WRB (2006) and USDA soil taxonomy (Soil Survey Staff 1999), examined soil were classified as: Order 7. Chernozemic soils (Polish: Gleby czarnoziemne; WRB: Chernozems, Phaeozems; ST: Mollisols - Aquolls, Udolls), Type 7.4. "Chernoziemic fluvisols" (Polish: Mady czarnoziemne; WRB: Mollic Fluvisol, Endofluvic Phaeozem; ST: Fluvaquentic Endoaquolls) and Type 7.6 "Mucky soils" (Polish: Gleby murszaste; WRB: Mollic or Umbric Gleysol; ST: Mollic or Histic Endoaquolls). 
Borek, Ł., Drymajło, K. (2019). The role and importance of irrigation system for increasing the water resources: the case of the Nida River Valley. Acta Sci. Pol., Formatio Circumiectus, 18 (3), 19-30. DOI: http://dx.doi.org/10.15576/ASP.FC/2019.18.3.19

Table 2. Designed and current parameters of ditches in the Kopernia object

\begin{tabular}{|c|c|c|c|c|c|c|c|c|c|c|c|}
\hline \multirow{3}{*}{$\begin{array}{l}\text { No. of } \\
\text { ditches }\end{array}$} & \multirow{2}{*}{$\mathrm{L}$} & \multicolumn{5}{|c|}{ Designed parameters of the cross-sections } & \multicolumn{5}{|c|}{ Current parameters of the cross-sections } \\
\hline & & $\mathrm{b}$ & $\mathrm{h}$ & $1: \mathrm{m}$ & A & V & $\mathrm{b}$ & $\mathrm{h}$ & $1: \mathrm{m}$ & A & V \\
\hline & {$[\mathrm{m}]$} & {$[\mathrm{m}]$} & {$[\mathrm{m}]$} & {$[-]$} & {$\left[\mathbf{m}^{2}\right]$} & {$\left[\mathbf{m}^{3}\right]$} & {$[\mathrm{m}]$} & {$[\mathrm{m}]$} & {$[-]$} & {$\left[\mathbf{m}^{2}\right]$} & {$\left[\mathbf{m}^{3}\right]$} \\
\hline $\mathrm{R}-12$ & 420 & 0.5 & 0.93 & \multirow{13}{*}{1.5} & 1.76 & 739 & 0.60 & 0.58 & \multirow{13}{*}{1.5} & 0.85 & 357 \\
\hline $\mathrm{R}-13$ & 440 & 0.5 & 0.71 & & 1.11 & 488 & 0.68 & 0.85 & & 1.66 & 730 \\
\hline $\mathrm{R}-14$ & 510 & 0.5 & 0.71 & & 1.11 & 566 & 0.84 & 0.70 & & 1.32 & 673 \\
\hline $\mathrm{R}-15$ & 544 & 0.5 & 0.63 & & 0.91 & 495 & 1.05 & 0.59 & & 1.14 & 620 \\
\hline $\mathrm{R}-16$ & 600 & 0.5 & 0.74 & & 1.19 & 714 & 0.80 & 0.67 & & 1.21 & 726 \\
\hline $\mathrm{R}-17$ & 656 & 0.5 & 0.73 & & 1.16 & 761 & 0.69 & 0.72 & & 1.27 & 833 \\
\hline $\mathrm{R}-18$ & 620 & 0.5 & 0.55 & & 0.73 & 453 & 0.62 & 0.88 & & 1.71 & 1060 \\
\hline $\mathrm{R}-19$ & 540 & 0.5 & 0.97 & & 1.90 & 1026 & 0.48 & 0.47 & & 0.56 & 302 \\
\hline $\mathrm{R}-20$ & 425 & 0.5 & 0.76 & & 1.25 & 531 & 0.48 & 0.48 & & 0.58 & 247 \\
\hline $\mathrm{R}-21$ & 408 & 0.5 & 0.73 & & 1.16 & 473 & 0.35 & 0.28 & & 0.22 & 90 \\
\hline $\mathrm{R}-22$ & 410 & 0.5 & 0.83 & & 1.45 & 595 & 0.70 & 0.53 & & 0.79 & 324 \\
\hline $\mathrm{R}-23$ & 340 & 0.5 & 0.65 & & 0.96 & 326 & 0.60 & 0.46 & & 0.59 & 201 \\
\hline $\mathrm{R}-\mathrm{B}$ & 1676 & 0.5 & 1.05 & & 2.18 & 3654 & 0.65 & 0.58 & & 0.88 & 1478 \\
\hline$\Sigma$ & 7589 & & & & & 10821 & & & & & 7641 \\
\hline
\end{tabular}

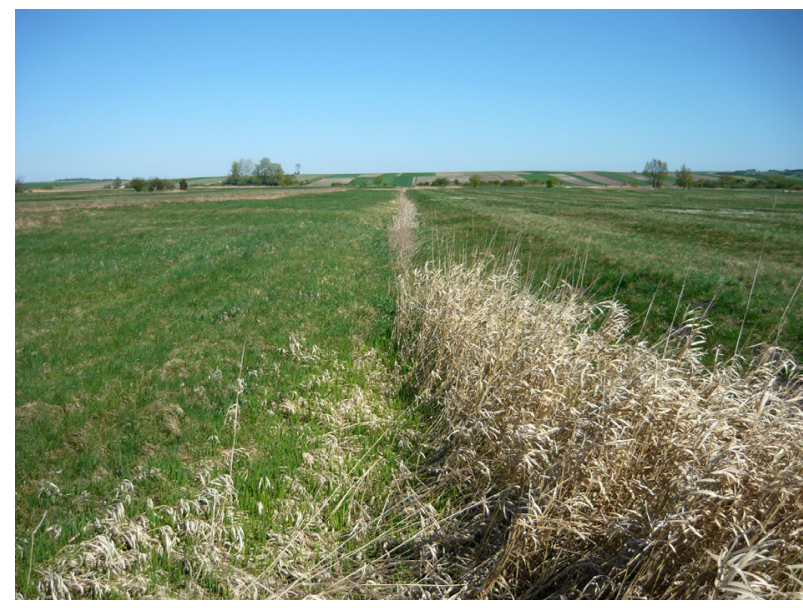

Fig. 3. Bushes and grass in the ditch (Photo by Łukasz Borek).

The major physical properties of the studied soils are presented in Table 4 . Mean particle density was $2.48 \mathrm{~g} \cdot \mathrm{cm}^{-3}$. Higher values in the second layers were observed. According to coefficient of variation $(\mathrm{CV})$, the behaviour in the soil can be considered as a low variability. Bulk density was in range 0.85 $-1.81 \mathrm{~g} \cdot \mathrm{cm}^{-3}$ and predominantly increasing with a depth and yielding a very high value for total porosity from $28.74 \%$ to $63.20 \%$. Mean soil moisture values

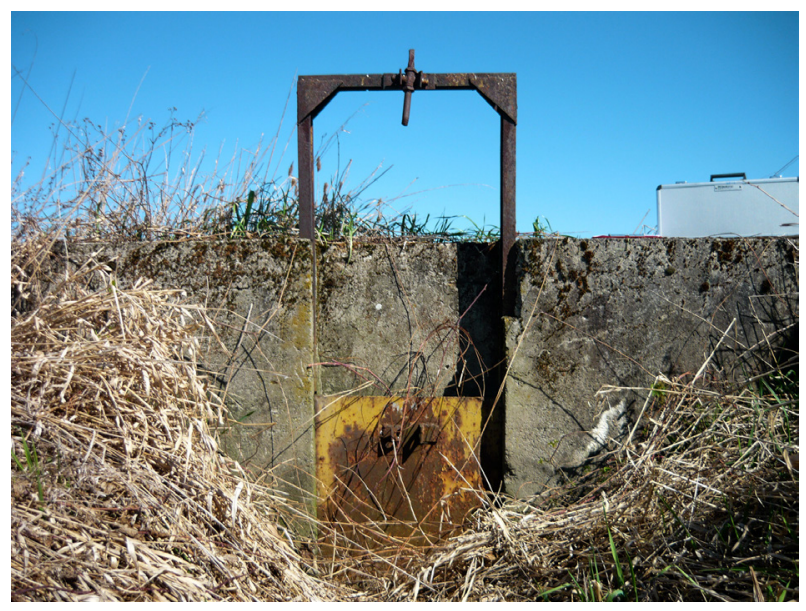

Fig. 4. A weir in the ditch (Photo by Łukasz Borek).

was $36.08 \% \mathrm{v} / \mathrm{v}$. In points No P.1 and P.2 higher values of soil moisture were observed in topsoil than in subsoil, while in point No P.3 it was the opposite. The high values of water storage ranged $19.71-91.70 \mathrm{~mm}$ in soil. Mean organic matter content, about 3.37\%, was highest in top layers and decreasing with depth. According to coefficient of variation (CV), the behaviour in the soil can be considered as a high variability. 
Borek, Ł., Drymajło, K. (2019). The role and importance of irrigation system for increasing the water resources: the case of the Nida River Valley. Acta Sci. Pol., Formatio Circumiectus, 18 (3), 19-30. DOI: http://dx.doi.org/10.15576/ASP.FC/2019.18.3.19

Table 3. Granulometric composition of soils with basic descriptive statistics

\begin{tabular}{|c|c|c|c|c|c|c|}
\hline \multirow{2}{*}{$\begin{array}{l}\text { No. of } \\
\text { measurement } \\
\text { points }\end{array}$} & \multirow{2}{*}{$\begin{array}{l}\text { Depth } \\
{[\mathrm{cm}]}\end{array}$} & \multirow{2}{*}{ Soil texture } & \multicolumn{3}{|c|}{ Soil particle percentage (\%) } & \multirow{2}{*}{$\begin{array}{l}\text { The fraction particles } \\
\text { below diameter of } \\
0.02 \mathrm{~mm}\end{array}$} \\
\hline & & & $\begin{array}{c}\text { sand } \\
2.0-0.05 \mathrm{~mm}\end{array}$ & $\begin{array}{c}\text { silt } \\
0.05-0.002 \mathrm{~mm}\end{array}$ & $\begin{array}{c}\text { clay } \\
<0.002 \mathrm{~mm}\end{array}$ & \\
\hline \multirow{2}{*}{ P. 1} & 10 & Sandy loam & 58 & 23 & 19 & 34 \\
\hline & 35 & Sandy loam & 73 & 14 & 13 & 37 \\
\hline \multirow{2}{*}{ P. 2} & 10 & Sandy loam & 78 & 14 & 8 & 23 \\
\hline & 35 & Sand & 96 & 2 & 2 & 19 \\
\hline \multirow{2}{*}{ P. 3} & 10 & Clay loam & 42 & 25 & 33 & 3 \\
\hline & 35 & Loamy sand & 80 & 13 & 7 & 52 \\
\hline D. 1 & 10 & Sandy loam & 53 & 29 & 18 & 11 \\
\hline \multicolumn{7}{|c|}{ Basic descriptive statistics } \\
\hline \multirow{6}{*}{ Index value: } & \multicolumn{2}{|c|}{ Minimum } & 42.0 & 2.0 & 2.0 & 3.0 \\
\hline & \multicolumn{2}{|c|}{ Maksimum } & 96.0 & 29.0 & 33.0 & 52.0 \\
\hline & \multicolumn{2}{|c|}{ Mean } & 68.6 & 17.1 & 14.3 & 25.6 \\
\hline & \multicolumn{2}{|c|}{ Median } & 73.0 & 14.0 & 13.0 & 23.0 \\
\hline & \multicolumn{2}{|c|}{ SD } & 18.5 & 9.2 & 10.3 & 16.7 \\
\hline & \multicolumn{2}{|c|}{ CV (\%) } & 27.0 & 53.4 & 71.8 & 65.3 \\
\hline
\end{tabular}

Table 4. Selected physical and water properties of soils with basic descriptive statistics

\begin{tabular}{|c|c|c|c|c|c|c|c|}
\hline \multirow{2}{*}{$\begin{array}{c}\text { No. of } \\
\text { measurement } \\
\text { points }\end{array}$} & Depth & $\begin{array}{c}\text { Mean particle } \\
\text { density }\end{array}$ & $\begin{array}{c}\text { Mean } \\
\text { bulk density }\end{array}$ & $\begin{array}{l}\text { Mean } \\
\text { total porosity }\end{array}$ & $\begin{array}{c}\text { Mean } \\
\text { actual } \\
\text { moisture }\end{array}$ & $\begin{array}{c}\text { Mean } \\
\text { water } \\
\text { storage }\end{array}$ & $\begin{array}{c}\text { Mean soil } \\
\text { organic } \\
\text { matter }\end{array}$ \\
\hline & {$[\mathrm{cm}]$} & \multicolumn{2}{|c|}{$\left[\mathrm{g} \cdot \mathrm{cm}^{-3}\right]$} & \multicolumn{2}{|c|}{$[\% \mathrm{v} / \mathrm{v}]$} & {$[\mathrm{mm}]$} & {$[\%]$} \\
\hline \multirow{2}{*}{ P.1 } & 10 & 2.36 & 1.05 & 55.57 & 38.61 & 38.61 & 4.9 \\
\hline & 35 & 2.52 & 1.35 & 46.43 & 30.99 & 77.46 & 2.4 \\
\hline \multirow{2}{*}{ P. 2} & 10 & 2.48 & 1.12 & 55.03 & 28.31 & 28.31 & 8.6 \\
\hline & 35 & 2.62 & 1.62 & 37.96 & 14.59 & 36.48 & 2.7 \\
\hline \multirow{2}{*}{ P.3 } & 10 & 2.30 & 0.88 & 61.74 & 57.92 & 57.92 & 3.6 \\
\hline & 35 & 2.62 & 1.80 & 31.34 & 33.73 & 84.32 & 0.4 \\
\hline D. 1 & 10 & 2.46 & 0.96 & 60.79 & 48.44 & 48.44 & 2.8 \\
\hline \multicolumn{8}{|c|}{ Basic descriptive statistics } \\
\hline \multirow{6}{*}{ Index value: } & Minimum & 2.17 & 0.85 & 28.74 & 7.88 & 19.71 & 0.24 \\
\hline & Maximum & 2.62 & 1.86 & 63.20 & 59.26 & 91.70 & 8.69 \\
\hline & Mean & 2.48 & 1.25 & 49.80 & 36.08 & 53.07 & 3.37 \\
\hline & Median & 2.49 & 1.11 & 54.00 & 33.03 & 53.37 & 2.81 \\
\hline & $\mathrm{SD}$ & 0.13 & 0.33 & 11.30 & 13.90 & 22.08 & 2.22 \\
\hline & $\mathrm{CV}$ & 5.29 & 26.57 & 22.69 & 38.53 & 41.61 & 65.91 \\
\hline
\end{tabular}


Borek, Ł., Drymajło, K. (2019). The role and importance of irrigation system for increasing the water resources: the case of the Nida River Valley. Acta Sci. Pol., Formatio Circumiectus, 18 (3), 19-30. DOI: http://dx.doi.org/10.15576/ASP.FC/2019.18.3.19

\section{Soil water retention}

Evaluation of the soil water retention balance in an alluvial floodplain with a shallow groundwater table was shown in table 5 and Figure 5. A system of canals and weirs allows it to increase or decrease the water level in a network of ditches and thereby control the water table. For the fraction particles below diameter of $0.02 \mathrm{~mm}$ at the mean level of $25.6 \%$ (see: Table 3) the values of empirical coefficients $a$ and $b$ were interpolated at 60 and $98 \%$, respectively. For medium soils (e.g. sandy loam), the minimum standard of drainage is $0.50 \mathrm{~m}$ and maximum standard of drainage is $0.70 \mathrm{~m}$ (Ostromęcki, 1973). Based on own calculations for sub-irrigation systems with variable groundwater level it was found that when the groundwater table was raised from $1.00 \mathrm{~m}$ to $0.70 \mathrm{~m}\left(\Delta \mathrm{h}_{1-2}=0.30 \mathrm{~m}\right)$, water volume corresponding to the net irrigation dose $\mathrm{dn}_{1}=65.6 \mathrm{~mm}$ would be supplied to the soil. The surface of 1 hectare gives the possibility of storage of $656 \mathrm{~m}^{3}$ of water in the soil. As a result of raising the groundwater table from
Table 5. Changes in soil retention at various levels of the water table

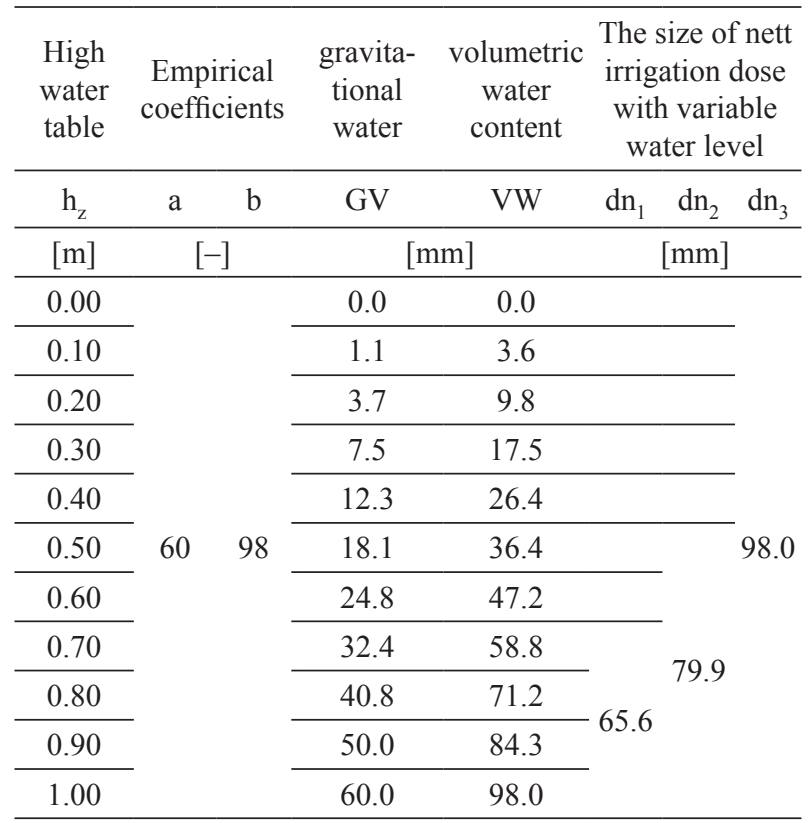

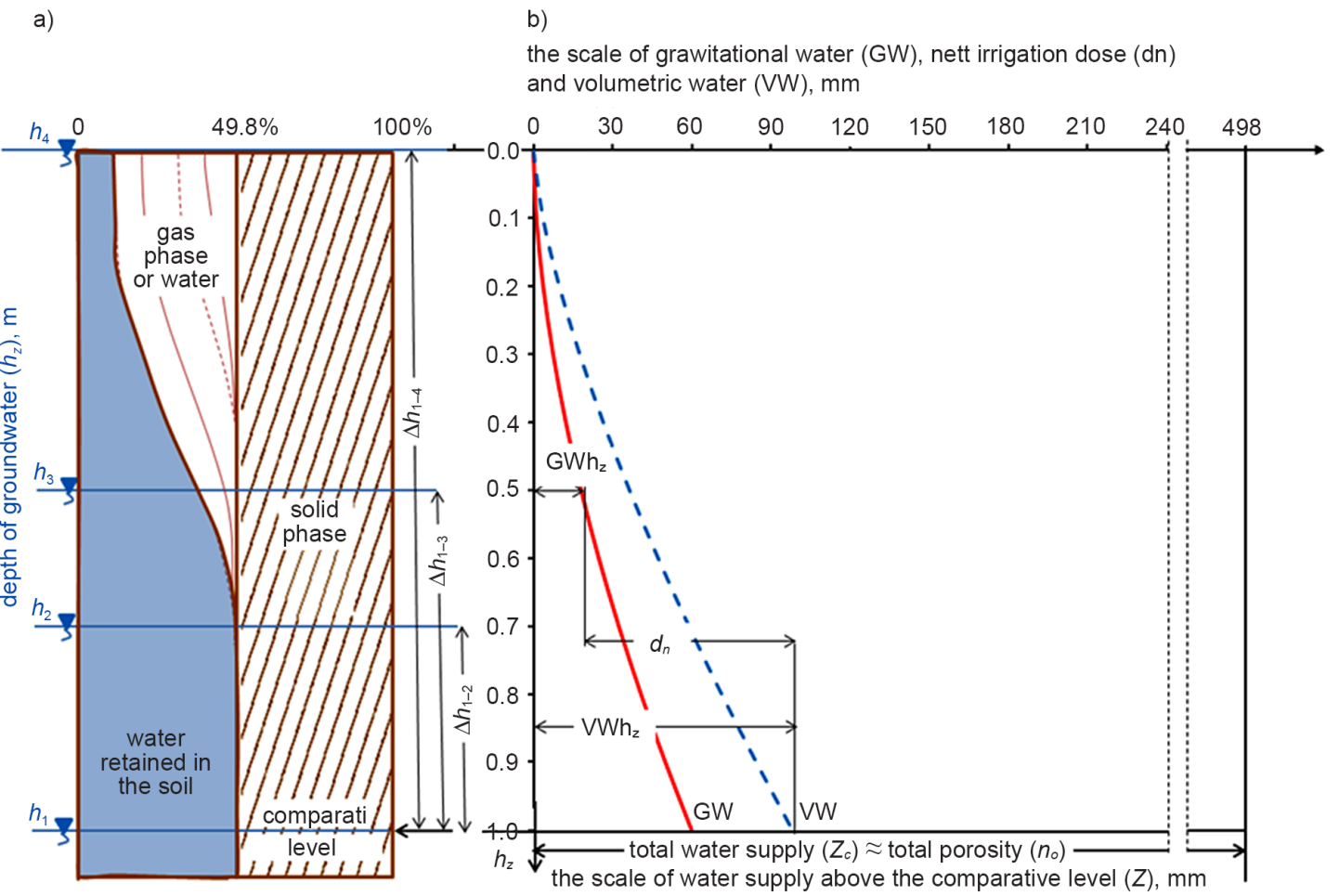

Fig. 5. Graph of soil water characteristics with shallow groundwater table: a) three-phase soil profile; b) water resources of the soil profile at different groundwater tables 
the level of $1.00 \mathrm{~m}$ to $0.50 \mathrm{~m}\left(\Delta \mathrm{h}_{1-3}=0.50 \mathrm{~m}\right)$, water volume corresponding to the net irrigation dose $\mathrm{dn}_{2}=$ $79.9 \mathrm{~mm}$ would be supplied to the soil. The surface of 1 hectare gives the possibility of storage of $799 \mathrm{~m}^{3}$ of water in the soil. If weirs will be completely filled (water table $=$ ground level, $\Delta \mathrm{h}_{1-4}$ ), water volume corresponding to the net irrigation dose $\mathrm{dn}_{3}=98.0 \mathrm{~mm}$ would be supplied to the soil, creating a potential to storage of $980 \mathrm{~m}^{3}$ water per hectare.

\section{Surface retention of water}

On the basis of table 2, surface retention by the irrigated object was estimated. The research shows that if ditches and weirs were kept in good condition, $10821 \mathrm{~m}^{3}$ of water could be retained at the Kopernia object.

\section{DISCUSSION}

The general condition of ditches and weirs in the Nida River Valley was unacceptable. The reason for such a state is lack of proper maintenance and conservation of irrigation network. There are more similar examples. Łabędzki (2015) reported decreased interest in utilization of water facilities and the cessation of irrigation system maintaining and conservation, which has a negative impact on the wetlands in the Noteć River valley. Iran Abbasi et al. (2015) noted that development of modern irrigation and drainage networks is one of effective strategies of preventing water losses and optimal usage of water resources in agricultural section. On the other hand, recent studies have shown that most of the existing networks, which have been constructed with huge costs, meet various social and technical obstacles. Akkuzu et al. (2008) indicates that maintenance of the Menemen irrigation system in Turkey is insufficient and suggested that farmers who benefit from the system should be given a more active role in maintenance work, and most importantly, that the institutions responsible for maintenance should be supported financially in these activities. Chandran and Ambili (2016) also argue that better maintenance of irrigation systems affect the efficiency of water management and it will be only possible with the participation of farmers. Very worrying phenomenon is water loss by technical irrigation devices totalling about $2 \%$ annually (Nyc and Pokładek, 2008). Permanent grasslands have the ability to save water and thus play an important role in the storage of soil organic matter and (Burczyk et al., 2018).

The examined alluvial soils in the Nida River Valley are very specific and diverse in terms of texture (Iqbal et al., 2005; Bullinger-Weber et al., 2007, Borek and Bogdał, 2018) and showed high sand content (Roj-Rojewski and Walasek, 2013). This feature may be related to the high mean organic matter content about 3.37\% (Rawls et al., 2003; Rubio and Poyatos, 2012). Dwevedi et al. (2017) noticed that alluvial soil has the highest productivity with respect to other soils, because it requires the least water due to its high porosity. Water dynamics in soil profile are governed by many factors that change vertically with depth and temporally in response to climate (O'Geen, 2013; Grzywna, 2012).

One of the possibilities of water storage in rural areas is soil and surface retention. This could be organised, for example, propering operation and maintenance of irrigation systems (Mioduszewski, 2014; Szpikowski et al., 2015). On the other hand, gravity-fed surface irrigation systems has garnered increasing attention at the political and bureaucratic levels due to frequent criticisms of its postulated low efficiency and high water wastage (Masseroni et al., 2017). On the Kopernia irrigated object with the area of 64.2 hectares, water volume from $42115.2 \mathrm{~m}^{3}$ to $62916 \mathrm{~m}^{3}$ can be stored in the soil profile, and in addition, in ditches $10821 \mathrm{~m}^{3}$ of water through surface retention. Increasing the small retention of parts of waters run-off into the sea will increase water resources in Poland, where it is estimated that from 45 to $70 \mathrm{~km}^{3}$ of water outflows into the Baltic Sea (Małecki and Gołębiak, 2012).

\section{CONCLUSIONS}

This paper examined soil water retention and surface retention in open irrigation ditches by using specific relationship between gravitational water and volumetric water content in soil. Through the measurements it was determined that capillary seepage from ditches provides an important contribution to soil water retention. The results of calculations show that in a soil profile we can store from $65.6 \mathrm{~mm}$ to $98.0 \mathrm{~mm}$ of water for a various combination of groundwater table 
position. These values indicate a large, but at present not used potential of the irrigation system. The alluvial soils in the Nida River Valley vary in texture: from sand, sandy loam to clay loam. These soils are dominated by sand, but contain enough clay and silt to provide some structure and fertility for water storage - on the day of field study the mean value of water storage in soil was $53 \mathrm{~mm}$ (in layer $0-35 \mathrm{~cm}$ ). Ditches with the total lenght of $7.6 \mathrm{~km}$ do not assure proper irrigation at this object, because they are shallow, silted with slime and lack proper bed gradient. Water damming was not working and so the hydrotechnical structures did not fulfil their functions. Lack of their systematic conservation is the reason of low soil water resources and surface retention. Proper exploiting and maintenance of irrigation ditches and weirs can increase surface retention by this object, even to $10821 \mathrm{~m}^{3}$ of water, making an important contribution to mitigation of local climate change. Nowadays, a major effort is required to modernize irrigation systems. Systems of open ditches cause decrease or increase of groundwater table level within the limits of the object, allowing its use for better soil moisture. Modernization of existing irrigation networks is one of the effective strategies of preventing water losses and optimal usage of water resources in agricultural section and of mitigating the effects of climate change, and also of providing a favourable conservation status of the natural habitats and biodiversity in this area.

\section{ACKNOWLEDGEMENTS}

We would like to thank the authorities of the Water Supervision in Jędrzejów for shared archival materials.

\section{REFERENCES}

Abbasi, N., Bahramloo, R., Movahedan, M. (2015). Strategic Planning for Remediation and optimization of Irrigation and Drainage Networks: A case study for Iran. Agriculture and Agricultural Science Procedia, 4, 211-221.

Akkuzu, E., Unal, H.B., Karatas, B.S., Avci, M., Aşik, Ş. (2008). Evaluation of Irrigation Canal Maintenance according to Roughness and Active Canal Capacity Values. Journal of Irrigation and Drainage Engineering, $134,1,60-66$.

Alarcón, J., Garrido, A., Juana, L. (2016). Modernization of irrigation systems in Spain: review and analysis for deci- sion ma king. International Journal of Water Resources Development, 32, 3, 442-458.

Borek, Ł., Bogdał, A. (2018). Soil water retention of the Odra River alluvial soils (Poland): Estimating parameters by RETC model and laboratory measurements. Applied Ecology and Environmental Research, 16 (4), 4681-4699.

Borek, Ł., Ostrowski, K. (2014). Rola i znaczenie infrastruktury wodno-melioracyjnej w kształtowaniu walorów krajobrazowych parku dworskiego w Brniu. Episteme, I, 4, 419-431.

Bullinger-Weber, G., Le Bayon, R., Guenat, C., Gobat, J. M. (2007): Influence of some physicochemical and biological parameters on soil structure formation in alluvial soils. - European Journal of Soil Biology, 43(1), 57-70.

Burczyk, P., Gamrat, R., Gałczyńska, M., Saran, E. (2018). Rola trwałych użytków zielonych w zapewnieniu stanu równowagi ekologicznej środowiska przyrodniczego. Water-Environment-Rural Areas, 18, 3(63), 21-37.

Carlson, E.A., Cooper, D.J., Merritt, D.M., Kondratieff, B.C., Waskom, R.M. (2019). Irrigation canals are newly created streams of semi-arid agricultural regions. Science of The Total Environment, 646, 770-781.

Chandran, K.M., Ambili, G.K. (2016). Evaluation of minor irrigation schemes using performance indicators: case studies from South India. Sustain. Water Resour. Manag, 2, 4, 431-437.

Dwevedi, A., Kumar, P., Kumar, P., Kumar, Y., Sharma, Y.K., \& Kayastha, A.M. (2017). 15 - Soil sensors: detailed insight into research updates, significance, and future prospects A2 - Grumezescu, Alexandru Mihai. Academic Press: New Pesticides and Soil Sensors, 561-594.

DZ.U. z 2017 poz. 1566 Prawo Wodne (Ustawa z dnia 20 lipca 2017 r.)

Ertsen, M.W. (2010). Structuring properties of irrigation systems: understanding relations between humans and hydraulics through modeling. Water History, 2, 2, 165-183 .

Grzywna, A. (2012). Changes in groundwater table levelin the dreinage transect Uhnin. Acta Sci. Pol., Formatio Circumiectus 11(3), 13-20.

GUS 2017. Ochrona środowiska. Informacje i opracowania statystyczne (Environmental protection. Statistical information and studies). Warszawa: Zakład Wydawnictw Statystycznych.

Iqbal, J., Thomasson, J. A., Jenkins, J. N., Owens, P. R., Whisler, F. D. (2005): Spatial Variability Analysis of Soil Physical Properties of Alluvial Soils. - Soil Science Society of America Journal Abstract, Soil \& Water Management \& Conservation, 69(4), 1338-1350. 
Kondracki, J. (2011): Regional geography of Poland. Warszawa: PWN.

Lecina, S., Isidoro, D., Playán, E., Aragüés, R. (2010). Irrigation Modernization in Spain: Effects on Water Quantity and Quality — A Conceptual Approach. International Journal of Water Resources Development, 26, 2, 265-282 .

Łapuszek, M. (2011). Studies on riverbed evolution on the Nida river at the Pińczów and Wiślica gauging station. Infrastructure And Ecology of Rural Areas, 12, 169-178 .

Leibundgut, Ch., Kohn, I. (2014a). European traditional irrigation in transition part I: irrigation in times past a historic land use practice across Europe. Irrigation and Drainage, 63, 3, 273-293.

Leibundgut, Ch., Kohn, I. (2014b). European traditional irrigation in transition part II: traditional irrigation in our time-decline, rediscovery and restoration perspectives. Irrigation and Drainage, 63, 3, 294-314.

Lozano, D., Arranja, C., Rijo, M., Mateos, L. (2010). Simulation of automatic control of an irrigation canal. 97, $1,91-100$.

Łabędzki, L. (2007). Irrigation in Poland - current status after reforms in agriculture and future development. J. Water Land Dev., 11, 3-16.

Łabędzki, L. (2015). Controlled run-off as a method of grassland irrigation and peatland preservation in the Notec river Valley. Infrastructure And Ecology Of Rural Areas, III/2, 717-726.

Łajczak, A. (2006). Regulacja rzeki a zagrożenie powodziowe, na przykładzie Nidy. Infrastruktura i Ekologia Terenów Wiejskich, 4, 1, 217-233.

Małecki, Z.J., Gołębiak, P. (2012). Zasoby wodne Polski i świata. Zeszyty Naukowe - Inzynieria Ladowa i Wodna w Kształtowaniu Środowiska, 7, 50-56.

Masseroni, D., Ricart, S., Ramirez de Cartagena, F., Monserrat, J., Gonçalves, J. M., de Lima, I., Facchi, A., Sali, G., Gandolfi, C. (2017). Prospects for improving gravity-fed surface irrigation systems in Mediterranean European contexts. Water, 9, 20.

Mays, L.W. (2010). Ancient Water Technologies. London: Springer.

Meijer K., Boelee E., Augustijn D. van der Molen I. (2006). Impacts of concrete lining of irrigation canals on availability of water for domestic use in southern Sri Lanka. Agricultural Water Management, 83(3), 243-251.

Mioduszewski, W. (2014). Small (natural) water retention in rural areas. J. Water Land Dev., No. 20 (I-III), 19-29.

Mocek, A., Drzymała, St. 2010. Geneza, analiza i klasyfikacja gleb. Poznań: Wyd. UP.
Nyc, K., Pokładek, R. (2008). Current problems of land reclamation in grasslands. Water-Environment-Rural Areas, 8, 2b (24), 97-103.

O'Geen, A. T. (2013) Soil Water Dynamics. Nature Education Knowledge, 4(5), 9.

Ostromęcki, J. 1973. Podstawy melioracji nawadniających. Warszawa: PWN.

PN-R-04032. (1998). Gleby i utwory mineralne. Pobieranie próbek i oznaczanie składu granulometrycznego. PKN.

PTG (2011): Polish soil classification. Fifth edition. - Soil Science Annual, 62(3).

Rawls, W.J., Pachepsky, Y.A., Ritchie, J.C., Sobecki, T.M., Bloodworth, H. (2003): Effect of soil organic carbon on soil water retention. Geoderma, 116 (1-2), 61-76.

Pierzgalski, E. (1990). Melioracje użytków zielonych nawodnienia podsiąkowe. Warszawa: Wydawnictwo SGGW.

Roj-Rojewski, S., Walasek, M. (2013). Muddy-alluvial soils catena near Suraż in the Upper Narew Valley. Soil Science Annual, 64, 2, 34-40.

Rubio, C. M., Poyatos, R. (2012). Applicability of Hydrus-1D in a Mediterranean Mountain Area Submitted to Land Use Changes. - International Scholarly Research Notice.

Soil Survey Staff (1999): Soil Taxonomy: A Basic System of Soil Classification for Making and Interpreting Soil Surveys. 2nd edition. - Natural Resources Conservation Service. U.S. Department of Agriculture Handbook, 436.

Somorowski, Cz. (1971). Materiały do ćwiczeń z melioracji rolnych - stosunki wodne. Warszawa: Wyd. SGGW.

Szpikowski J., Szpikowska G., Domańska M. (2015). Old melioration systems: the influence onto functioning of geoecosystems of river valleys in the Parsęta (NW Poland). Quaestiones Geographicae, 34(3): 129-140.

Vassena, Ch., Rienzner M., Ponzini G., Giudici M., Gandolfi C., Durante C., Agostani D. (2012). Modeling water resources of a highly irrigated alluvial plain (Italy): calibrating soil and groundwater models. Hydrogeology Journal, 20, 3, 449-467.

Wahlin, B., Zimbelman, D. (2017). Canal Automation for Irrigation Systems: American Society of Civil Engineers Manual of Practice Number 131. Irrigation and Drainage, 67, 1, 22-28.

WRB. World Reference Base for Soil Resources 2006. World Soil Resources Reports No. 103. FAO: Rome.

Zaghloul, E.A., Hassan, S.M., Bahy, El-Dein, A.M., Elbeih, S.F. (2013). Detection of ancient irrigation canals of Deir El-Hagar playa, Dakhla Oasis, Egypt, using Egyptsat-1 data. The Egyptian Journal of Remote Sensing and Space Science, 16, 2, 153-161. 


\section{ROLA I ZNACZENIE SYSTEMU NAWADNIAJĄCEGO W ZWIĘKSZANIU ZASOBÓW WODNYCH: PRZYPADEK DOLINY RZEKI NIDY}

\section{ABSTRACT}

\section{Cel pracy}

W niniejszym artykule przedstawiono rolę i znaczenie systemu nawadniania grawitacyjnego w zwiększaniu zasobów wody glebowej i retencji powierzchniowej w piaszczystych glebach aluwialnych.

\section{Materiat i metody}

Badania przeprowadzone na obiekcie Kopernia (64,2 ha) w dolinie rzeki Nidy (powiat pińczowski, województwo świętokrzyskie) dotyczyły systemów nawodnień podsiąkowych powstałych w drugiej połowie XX wieku. Do określenia zmian retencji wodnej w glebie na obiekcie zastosowano charakterystyki wodne gleby, takie jak odciekalność i objętość rezerw przejściowych przy różnym położeniu zwierciadła wody gruntowej. W celu określenia retencji powierzchniowej zostały użyte materiały archiwalne (projekt techniczny) oraz wykonano badania terenowe (inwentaryzacja rowów, pobór próbek glebowych). Dodatkowo, w laboratorium określono wybrane właściwości fizyko-wodne gleb aluwialnych.

\section{Wyniki i wnioski}

Na podstawie przeprowadzonej inwentaryzacji rowów i budowli hydrotechnicznych oraz badań polowych i laboratoryjnych wykazano, że podczas prawidłowego funkcjonowania systemu nawadniania, w glebie mogłaby zostać zmagazynowana woda w ilości od 42 115,2 $\mathrm{m}^{3}$ do $62916 \mathrm{~m}^{3}$, a dodatkowo w rowach $10821 \mathrm{~m}^{3}$ wody jako retencja powierzchniowa. Niektóre systemy irygacyjne mogłyby zostać wykorzystane do powiększenia terenów podmokłych, a także do zwiększenia małej retencji wodnej. Jednak takie zmiany wymagałyby znacznych wkładów finansowych i czasu na przeprowadzenie tych dostosowań do aktualnych wymogów polityki wodnej i zmian klimatu.

Słowa kluczowe: zmiany klimatu, retencja glebowa, retencja powierzchniowa, rowy otwarte, systemy nawadniające 